\title{
Consumer-based Brand Equity in the Service Shop
}

\author{
Teck Ming Tan ${ }^{1}$, Tze Wei Liew ${ }^{1}$, Lee Soon Siong William ${ }^{1}$, Ong Bee Fang Michelle ${ }^{1} \&$ Su-Mae Tan ${ }^{1}$ \\ ${ }^{1}$ Centre for Diploma Programme, Multimedia University, Melaka, Malaysia \\ Correspondence: Teck Ming Tan, Centre for Diploma Programme, Multimedia Univeristy, Melaka, Malaysia. \\ E-mail: sobbez@gmail.com
}

Received: May 7, 2012 Accepted: May 25, 2012 Online Published: July 25, 2012

doi:10.5539/ijms.v4n4p60 URL: http://dx.doi.org/10.5539/ijms.v4n4p60

\begin{abstract}
This present study investigated the causal relationships among the dimensions of consumer-based brand equity in the context of service shop; and to improve the conceptualization of service quality, which serves as a sub-dimension of perceived quality. A total of 602 self-administrated questionnaires were distributed via non-probability sampling. Findings suggested that the dimensions of service quality in the service shop were comprised of tangibles, responsiveness, empathy, assurance, recovery, and knowledge. The causal effects of service quality are significantly greater than product cues in formatting favorable consumer response towards the brand. The major contribution is that it provides imperative insight into the development of consumer-based brand equity in the service industry that is based on typology-specific. Future study should include simultaneous examination of the four service quadrants as classified by Schmenner's (1986), and investigates the universal dimensional of consumer-based brand equity in service industry by typology-specific.
\end{abstract}

Keywords: brand equity, service quality, service levels, service shop, structural model

\section{Introducation}

Brand equity is the tremendous value inherent in a famous brand name, and refers to the attractiveness of the brand name associated to the products or services (Bello \& Holbrook, 1995). Prior researchers have identified positive impacts yielded by brand equity on profitability of companies, sustainability of cash flows (Srivastava \& Shocker, 1991), sustainability of competitive advantages (Szymanski, Bharadwaj, \& Varadarajan, 1993), growth and stability of stock prices (Simon \& Sullivan, 1993), firms' performances (Kim \& Kim, 2005), successfulness of marketing efforts (Styles \& Ambler, 1995), willingness of consumers to pay premium prices (Keller, 1993), and greater online brand experience (Tan \& Devinaga, 2010).

The study of brand equity has received substantial interest from academicians and practitioners in recent years, for instance the investigation of brand equity dimensions (Aziz \& Yasin, 2010; Bamert \& Wehrli, 2005; Pike, Bianchi, Kerr, \& Patti, 2010; Rosa \& Riquelme, 2008; Tong \& Hawley, 2009; Yasin, Noor, \& Mohamad, 2007), brand equity outcome (Kim \& Kim 2004, 2005; Henry, Catherine, \& Ada, 2010; Wang, Wei, \& Yu, 2008) and the relationship between the traditional "4 Ps" marketing activities and brand equity (Angel \& Manuel, 2005; Gil, Andrés, \& Salinas, 2007; Yoo, Donthu, \& Lee, 2000). According to Xu and Andrew (2009), the development of brand equity in the service industry relied heavily on the performance levels of service providers; it refers to the perception of consumers towards the service quality (Brady \& Cronin, 2001). In other words, service quality is considered an essential element of the consumer-based brand equity in the service sector.

The importance of consumer-based brand equity has been investigated in consumer markets in different studies but there is a lack of research in service market (Bamert \& Wehrli, 2005). The lack of research regarding service brand measurement may be an indication of the complexity involved in understanding how consumers evaluate a service provider. For instance, past researchers have debated the universal conceptualization of service quality. Studies (Lapierre, 1996) have proposed that service construct should not only be operational (non-global), but should also be context-specific.In addition, there is a standing dilemma between different measurements of the service quality construct: expectation minus perceptions (Parasuraman, Zeithaml, \& Berry, 1988) or performance-based (Cronin \& Taylor, 1992). Yet, there are scholars who suggested that service quality should be measured based on the degree of consumer contact and customization with labor intensity (Schmenner, 1986). Olorunniwo, Hsu, and Udo (2006) markedly suggested that service quality should be measured using a typology-specific framework. However, research on the measurement of service quality using typology-specific 
framework is still scarce with a limited number of studies focusing on other quadrants of Schmenner's (1986) classifications (Olorunniwo et al., 2006). The main objective of this study was to validate the measurement of service quality using a typology-specific framework, and to investigate the relationships between the dimensions of brand equity. In retrospect, the findings from this study would provide practitioners with a deeper understanding in regards to brand management of service providers.

\section{Research Framework and Research Hypotheses}

\subsection{Consumer-based Brand Equity in Service Shop}

Aaker (1991) suggested five dimensions of brand equity, namely perceived quality, brand awareness, brand association, brand loyalty, and other proprietary assets. In the hospitality-based industry, Kim and Kim (2005) asserted that brand awareness and perceived quality significantly affect the performance of restaurant chains. The authors also posited that brand awareness, brand loyalty, perceived quality, and brand image constitute the dimensions of brand equity. In service market, service quality is a part of the perceived quality (Bamert \& Wehrli, 2005). In addition, Muller (1998) highlighted that restaurant chains (service shop) should focus on three key areas, which are execution of service delivery, quality products and services, and establishing a symbolic and evocative image. He further argued that these strong combinations have been attributed to gaining the opportunity in charging premium prices and enhancing customer loyalty. That is, both service quality and product quality serve as important criteria in measuring perceived quality, and the creation for both qualities has to be focused on consumers' perceptions, rather than on actual quality (Aaker, 1996). Most of the time, consumers depend on cues associated with quality. The reason being that consumers may not always have ample time and motivation to utilize every information that contribute to a rational and objective judgment (Aaker, 1991). Therefore, the key factor to influence perceived quality is to understand and manage the little things that consumers use as the basis for making a judgment of quality, which could be referred to as product cues (Aaker, 1996). With Aaker's brand equity model, this study sets out to retest the measurement of consumer-based brand equity with restaurant brands in the service shop market.

\subsection{Service Typology}

According to Cook, Goh, and Chung (1999), service typology can be classified into two specific dimensions; marketing-oriented and operations-oriented. Cook and his colleagues recommended the significance of interaction and integration of dimensions to service providers in order to express strategies and tactics for service improvement. In addition, Olorunniwo et al. (2006) empirically proved that service quality can be measured using a typology-specific framework, based on the classification scheme proposed by Schmenner (1986). Such contributions have led to research interests in bringing parsimony to have better understanding of the characteristics that distinguish between service providers. Based on the degree of labor intensity and interaction/customization, Schmenner (1986) distinguished four quadrants of classified services in the service process system: service factory, service shop, mass services, and professional services. In this respect, this study positioned restaurant chains as service shop.

\subsection{Service Quality Dimensions in the Service Shop}

This study established service quality as typology-specific for two primary reasons; firstly, the utilization of a universal conceptualization of the service quality paradigm may be incapable of producing any results (Lovelock, 1983) and secondly, the quality of operational measures is important for the study of service quality (Lapierre, 1996). The dimensions of service quality in the service shop are illustrated next, based on the research methodology of Olorunniwo et al. (2006). According to Schmenner (1986), service shop (restaurant chains) typically invests less on labor costs. Instead, restaurant chains often focus their investments on improving the technology of plant and equipment, as well as the overall physical environment (tangibles). In addition, restaurant chains adopt standard operating procedures to standardize their business processes and procedures (assurance). Schmenner (1986) also noted that service shop is unique for two reasons; firstly it has a high level of consumers' interaction with the service processes and secondly, it provides customized business services. Due to these distinctive nature, the quality of service shop often relies on human capital e.g. waiter, delivery person etc. (knowledge). Quality of service shop can also be extended by providing positive responses to consumers (responsiveness) and taking instantaneous corrective actions upon unwanted or unanticipated events (recovery). Customized business service is another unique characteristic of the service shop. Consumers can actively intervene in the service process, such as requesting for additional services or for particular attention. Service customization in restaurant chains today allow for "add on" items, change of beverages, customized set meals, variations of choices from the menu, self-service salad bars, make your own pizzas, 24-hour operations, drive-through or home deliveries (empathy). Ideally, service shop optimized the customization of service 
providers for the purpose of increasing customer satisfaction. Reliability is defined as the ability to perform the proposed service dependably and accurately. It includes qualities such as dependability, consistency, accuracy, and right the first time (Zeithaml, Parasuraman, \& Berry, 1990). Arguably, reliability might not serve as a vital dimension in the context of service shop. This is mainly because of the high investments in technological equipment and standard operating procedures that will contribute to the consistency and accuracy of business performances. Based on the review of literature, we hypothesized that:

H1: In the perspective of service shop, the dominating dimensions of service quality are "Tangibles", "Responsiveness", "Empathy", "Assurance", "Recovery", and "Knowledge". "Reliability" might not serve as an important dimension in the context of service shop.

\subsection{Relationships among the Dimensions of Consumer-based Brand Equity}

Dodds, Monroe, and Grewal (1991) stated that brand awareness could have a positive effect on consumers' perceptions of quality and value, because it allows consumers to associate the brand with its product category. Brand awareness also refers to the strength of a brand's presence in consumers' minds (Aaker, 1996). In a study conducted on bicycle brands, Grewal, Krishnan, Baker, \& Borin (1998) revealed a positive and significant relationship between brand awareness and product quality. As a result, this study concluded that there is positive correlation between brand awareness and food quality as perceived by consumers. According to brand knowledge (Keller, 1993), good evaluation of perceived quality will increase brand image. Therefore, good perception of food quality would drive to a positive brand image as there are strong, favorable, and unique associations linked to the brand due to greater brand attributes, benefits, and attitudes as perceived by consumers. Roberts, Morrison, Chandrashekaran, and Gordon (2004) justified that there is a causal order between perceived quality and loyalty, based on the purchase decision stages. That is, perceived quality was related to the information evaluation stage and brand loyalty was mainly associated to the purchase decision stage (Roberts et al., 2004). Hence, positive evaluation of food quality has led to a higher possibility of brand loyalty, evidenced by repeated purchase behavior. Brand awareness affects consumers' decision making by influencing the formation and strength of associations in brand image. According to Hoyer and Brown (1990), brand awareness generated differences in information processing, and these differences, which were created by brand associations in consumers' memories, directly affect brand image. Keller $(1993,1998)$ presented that brand image is the combination of favorability, strength, and uniqueness of brand associations. Thus, if consumers have favorable images towards a certain brand, then this process will lead to a positive influence on consumers' trust (Esch, Langner, Schmitt, \& Geus, 2006; Flavián, Guinalíu, \& Gurrea, 2006; Tan, Hishamuddin, \& Devinaga, 2011) and eventually reinforce their loyalty (Kandampully \& Hu, 2007; Tan, Tan, William, Michelle, \& Liew, 2012). Based on this premises, we hypothesized that:

H2a: Food quality and brand awareness are positively correlated.

H2b: Food quality has a significant positive impact on brand image.

H2c: Food quality has a significant positive impact on brand loyalty.

H2d: Brand awareness has a significant positive impact on brand image.

H2e: Brand image has a significant positive impact on brand loyalty.

Service quality has a positive relationship with brand awareness, especially in the service industry. A study involving respondents of a bank revealed that service quality is significantly correlated with brand awareness (Zain, 2007). In addition to that, service quality has a significant positive effect on perceived brand name value (Malai \& Spece, 2010), and this in turn contributes to company awareness and corporate image (Andreas, 2001). According to Aydin and Ozer (2005), service quality is a function of consumers' consumption experiences, and these experiences lead to the formation of brand image. Hence, consumers' perceptions about service quality directly affect brand image. Paul, Gary, and Hsiao (2010) supported this fact; their studies revealed that service quality has a direct and positive effect on brand image. Their research also suggested that managers can enhance consumers' perceptions of private label brand image by improving the service quality related to the private label brands. Service quality is considered an antecedent to customer satisfaction (Cronin \& Taylor, 1992; Rust \& Oliver, 1994) and subsequently, customer satisfaction a determinant of brand loyalty (Aaker, 1996). There is a positive and significant direct relationship between consumers' perceptions of service quality and their intentions to re-purchase, as well as willingness to recommend to others (Boulding et al., 1993; Parasuraman et al., 1988). In addition to this, service providers that provide top-notch service quality will contribute to customer loyalty in service organizations (Gwinner, Gremler, \& Bitner, 1998) and relationship stability (Hennig-Thurau \& Klee, 1997). Based on the discussions above, the following hypotheses were derived as below and a proposed 
framework for consumer-based brand equity in the service shop was presented in Figure 1:

H3a: Service quality and brand awareness are positively correlated.

H3b: Service quality has a significant positive impact on brand image.

H3c: Service quality has a significant positive impact on brand loyalty.

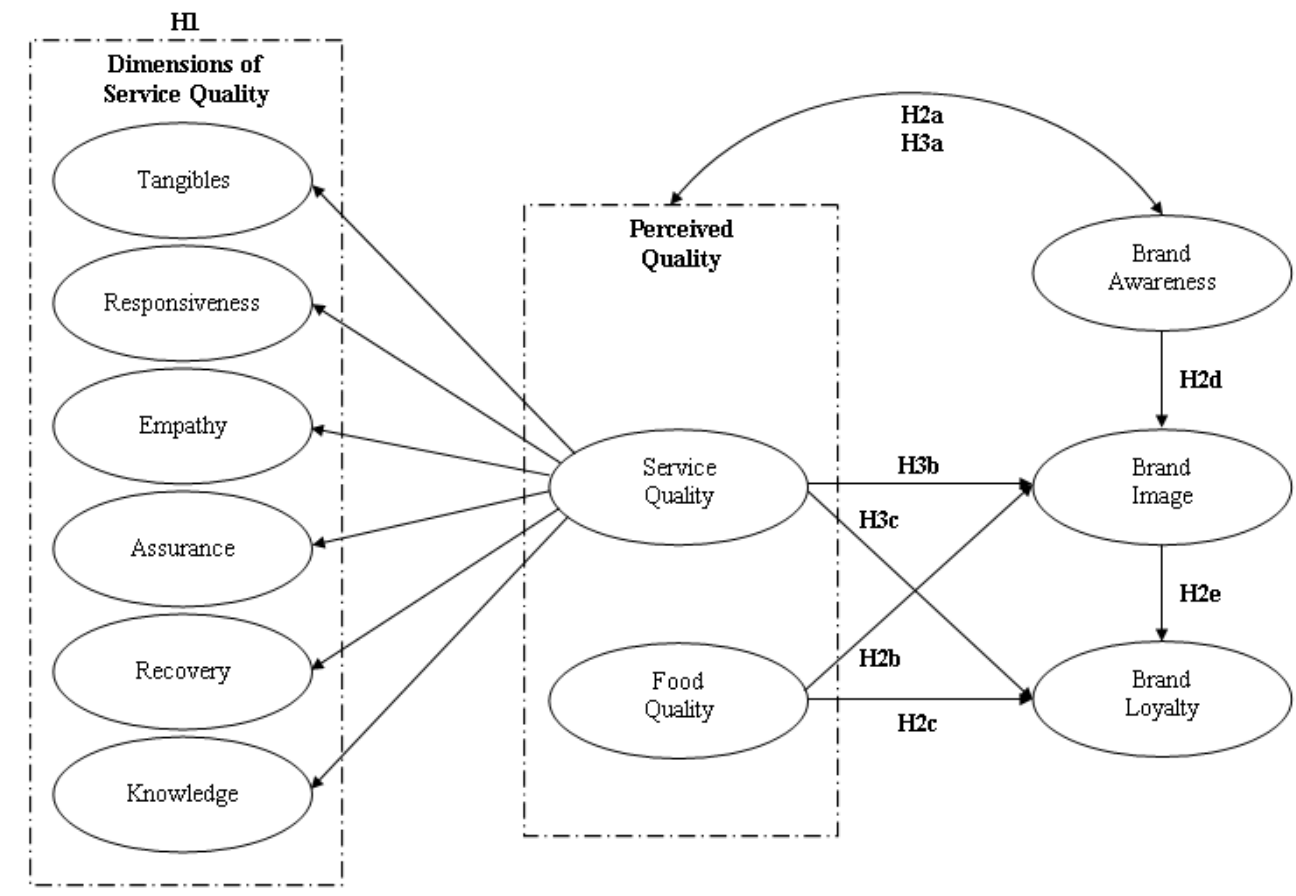

Figure 1. A proposed framework for consumer-based brand equity in service shop

\section{Research Methodology}

\subsection{Instrument and Measures}

Five measurement items of brand loyalty were adapted from Aaker (1991) and one item from Yoo et al. (2000). Referring to Keller's (1993) study on brand knowledge, there are two sub-dimensions of brand awareness, namely brand recognition and brand recall. Primarily, Keller (1998) declared that brand recognition takes place when consumers are able to confirm the brand, when a brand is given as a cue, even before brand exposure. On the other hand, brand recall takes place when consumers are able to recover a brand from memory, when cued with a given product category, the needs fulfilled by the category, or purchase and usage situations. Due to its applicability in self-administrated questionnaires, the element of brand recognition was incorporated in the design of the measurement of brand awareness. Two items were adapted from Aaker (1991), another two items from Yoo et al. (2000), and one item from Gil et al. (2007). The measurement of eight brand image items was employed from Kim and Kim (2005). These scales were adapted as they are similarly based on restaurant chains. The final measure, food quality was measured as perceived in consumers' minds subjectively. Using Johns and Howard (1998) and Kivela, Inbakaran, and Reece (1999) items, our study had adapted four items: "X meals are fresh" "X meals are well-cooked" "X meals are well-presented" and "X offer a variety of food and beverages". For the measurement of "Tangibles", "Responsiveness", "Empathy", "Assurance", and "Reliability", SERVQUAL scales by Parasuraman et al. (1988) were adapted. This study made minimal wording changes to the original content of the instrument; the focus of this study was on the performance (SERVPERF) rather than on consumers' expectations and perceptions. This focus was deemed appropriate because the intent of this research is to examine the relative importance of the performance dimensions. The measurement of three "Recovery" items were employed from Olorunniwo et al. (2006), and one item was adapted from Parasuraman, Zeithaml, and Berry (1985). The final measure "Knowledge" was adapted from the works of Olorunniwo et al. (2006); based on their study of service factory. All the variables were measured using six-point scales. 


\subsection{Pilot Study}

Table 1. Results of Cronbach's Alpha, Skewness and Kurtosis for pilot study

\begin{tabular}{llll}
\hline Instrument Items & $\begin{array}{l}\text { Cronbach's } \\
\text { Alpha }\end{array}$ & Skewness & Kurtosis \\
\hline Tangibles & 0.79 & -0.78 to -0.23 & -0.25 to 1.34 \\
Responsiveness & 0.73 & -0.31 to -0.18 & -0.08 to 0.74 \\
Empathy & 0.76 & -0.81 to -0.37 & -0.43 to 0.81 \\
Assurance & 0.83 & -0.47 to -0.11 & -0.45 to 0.98 \\
Reliability & 0.73 & -0.63 to -0.08 & 0.15 to 0.67 \\
Recovery & 0.85 & -0.38 to 0.08 & -0.43 to 0.07 \\
Knowledge & 0.77 & -0.55 to -0.20 & -0.18 to 0.11 \\
Food quality & 0.79 & -0.66 to -0.17 & -0.40 to 1.16 \\
Brand Awareness & 0.76 & -1.23 to -0.31 & -0.55 to 1.91 \\
Brand Image & 0.80 & -0.42 to 0.01 & -0.64 to 0.69 \\
Brand Loyalty & 0.90 & -0.41 to -0.09 & -0.60 to 0.34 \\
\hline
\end{tabular}

To assess the clarity of the question as well as the reliability and validity of the variable measures, a pilot study was first conducted by collecting surveys based on 150 undergraduate students. According to Nunnally (1978), alpha coefficient between 0.50 and 0.60 is considered sufficient for pilot study. Referring to the results in Table 1, the range for Cronbach's Alpha was from 0.73 to 0.90, which satisfied the cut-off value as suggested, and indicated internal consistency of the constructs. Normality is tested according to the common rule-of-thumb, which is to run descriptive statistics to determine both Skewness and Kurtosis. According to Tong (2006), both Skewness and Kurtosis should be within the absolute value of 2 to indicate that the data are normally distributed. The results showed that the values of Skewness and Kurtosis of all the observed variables were within the absolute value of 2 . Therefore, all of the listed instruments were used in the main study. Minor amendments were made on the arrangement and clarity of certain questions. The final version of instruments was presented in Appendix I.

\section{Findings}

Data was collected from a non-probability sample of six major shopping complexes in Malaysia (Sunway Pyramid, Berjaya Times Square, Mid Valley Megamall, Pavilion Kuala Lumpur, Dataran Pahlawan Megamall, and Mahkota Parade Shopping Mall) from August 13, 2010 to October 9, 2010. Based on respondents' last visitations and familiarity, they were allowed to select one of the seven restaurant chains (Starbucks, OldTown White Coffee, McDonalds', Pizza Hut, KFC, Sushi King or Secret Recipe) to complete an English version self-administered questionnaire. All variables were assessed through the respondents' perceptual evaluations and the recall of their experiences. Instructions emphasized that "there are no right or wrong answers; only your personal opinions matter" to minimize possible response bias (Aronson, Ellsworth, Carismith, \& Gonzales, 1990). Each respondent were given a gift token upon completion of the questionnaire.

\subsection{Profile of Respondents}

A total of 602 respondents participated in the survey and 40 were excluded due to incomplete responses. Thus, 562 questionnaires were used for further analysis; the profile of respondents was shown in Table 2. Out of the pool of respondents, $49 \%$ were men and $51 \%$ women. With respect to ethnic groups, $52 \%$ were Malay, followed by Chinese (35\%), others (7\%), and Indian (6\%). Majority of respondents $(90 \%)$ were below the age of 30 and earned less than RM 3,500 in monthly income (89\%). Students dominated almost half of the sample size (49\%), followed by private sector employees (34\%), government servants (9\%) and self-employed individuals (8\%). The frequency distribution for monthly visitations were as follow: $39 \%$ one time, $31 \%$ two times, $13 \%$ three times, $17 \%$ four times and above. 
Table 2. Description of respondents

\begin{tabular}{llll}
\hline Item & Description & Frequency & Percentage \\
\hline Gender & Male & 275 & 49 \\
Ethnicity & Female & 287 & 51 \\
& Malay & 290 & 52 \\
& Chinese & 198 & 35 \\
Age Group & Others & 36 & 6 \\
& 20 years old or less & 38 & 7 \\
& $21-25$ years old & 204 & 36 \\
& 26 - 30 years old & 201 & 36 \\
Respondents' Income & 31 - 35 years old & 100 & 18 \\
& 36 - 40 years old & 31 & 6 \\
& Above 40 years old & 19 & 3 \\
& RM 1,500 and below & 7 & 1 \\
& RM 1,500 - RM 2,500 & 318 & 57 \\
& RM 2,500 - RM 3,500 & 712 & 20 \\
& RM 3,500 - RM 4,500 & 27 & 12 \\
Occupation & RM 4,500 - RM 6,000 & 14 & 5 \\
& Above RM 6,000 & 21 & 2 \\
& Government Servant & 49 & 4 \\
& Private Sector & 192 & 9 \\
Number of Visit per Month & Self-employed & 45 & 34 \\
& Student & 276 & 8 \\
& 1 time & 219 & 39 \\
& 2 times & 174 & 31 \\
& 3 times & 73 & 13 \\
& $>4$ times & 96 & 17 \\
\hline
\end{tabular}

\subsection{Data Analysis}

The instrument validation process of service quality was based on the recommendation by Hair, Black, Babin, and Anderson (2010) and Lu, Lai, and Cheng (2007). Firstly, exploratory measurement assessment was carried out using corrected item-total correlation; the recommended cut-off value is 0.50 . This was followed by factor analysis with varimax rotation technique and principal components as the estimated method. The factor solution should explain at least half of each original variable's variance, thus communality value for each item should be 0.5 or higher. Following a conventional heuristic, item which carry a loading smaller than 0.4 on any factors were omitted. Furthermore, items that revealed cross-loadings greater than 0.4 on more than one factor were dropped because they did not provide a pure measure of a specific construct. Next, structural equation modeling (SEM) was conducted using SPSS AMOS (version 16) in two sub-models: a measure model and a structural model. First, a confirmatory factor analysis (CFA) identified the measurement model, which showed the relationship between the observed and latent variables. Fit indices included in the present study were the root mean square error of approximation (RMSEA), standardized root mean square residual (SRMR), goodness-of-fit index (GFI), adjusted goodness-of-fit index (AGFI), normed fit index (NFI), comparative fit index (CFI), and incremental fit index (IFI). The zero value for both SRMR and RMSEA indicated perfect fit, but models that score 0.8 or less on RMSEA and 0.5 or less on RMR are indicated to have sensible fit (Browne and Cudeck, 1993). A value greater than 0.8 is desirable for AGFI, and values greater than 0.9 are desirable for CFI and NFI (Anderson \& Gerbing, 1988). Besides, a comprehensive assessment of construct validity was conducted, including convergent and discriminant validity (Bentler, 1983). In addition, a third-order CFA was performed to provide a convincing model for both reliability and validity test (Marsh \& Hocevar, 1985). Finally, analysis of structural model was performed to estimate the relationships among latent variables, and also to test the complex relationships among constructs as hypothesized from literature review. 


\subsubsection{Assessing Fit between Proposed Models and Data}

The 52-items instrument was first assessed for corrected item-total correlations (CITC), six items (T2, T4, F4, BA5, BI4, and BI5) were removed since the CITC value were lower than 0.50, showing that items were not measuring the same construct from the rest of the items (Lu et al., 2007). Next, exploratory factor analysis was used to determine the number of factors for service quality in service shop. The 27 -items instrument was analyzed using varimax rotation technique. $\mathrm{K} 3, \mathrm{~L} 1, \mathrm{~L} 2$, and $\mathrm{R} 1$ were removed from the next iteration of the principal component analysis due to failure in satisfying communalities value of 0.50 . According to Hair et al. (2010), it is common to consider a solution of about $60 \%$ as satisfactory in social sciences research. Table 3 showed the cumulative percent of explained variance was $60.22 \%$. The eigenvalues was 9.80 for recovery/knowledge, 1.76 for responsiveness/assurance, 1.20 for empathy, and 1.10 for tangibles. Cross-loading item, such as L4 was eliminated; consequently, there was only one variable representing the construct of reliability, which was L3. As hypothesized in literature review, reliability is not a dominant dimension for service shop; therefore, the exclusion of reliability construct was empirically proven in this study.

Table 3. Factor loadings for the underlying dimensions of service quality

\begin{tabular}{|c|c|c|c|c|}
\hline Items & $\begin{array}{l}\text { Recovery/ } \\
\text { Knowledge }\end{array}$ & $\begin{array}{l}\text { Responsiveness/ } \\
\text { Assurance }\end{array}$ & Empathy & Tangibles \\
\hline C1 & 0.69 & & & \\
\hline C2 & 0.76 & & & \\
\hline C3 & 0.75 & & & \\
\hline C4 & 0.74 & & & \\
\hline K1 & 0.62 & & & \\
\hline K2 & 0.57 & & & \\
\hline A1 & & 0.64 & & \\
\hline A2 & & 0.68 & & \\
\hline A3 & & 0.66 & & \\
\hline A4 & & 0.47 & & \\
\hline R2 & & 0.73 & & \\
\hline R3 & & 0.66 & & \\
\hline R4 & & 0.64 & & \\
\hline L3 & & 0.60 & & \\
\hline L4 & 0.61 & 0.40 & & \\
\hline E1 & & & 0.61 & \\
\hline E2 & & & 0.73 & \\
\hline E3 & & & 0.80 & \\
\hline E4 & & & 0.73 & \\
\hline T1 & & & & 0.66 \\
\hline T3 & & & & 0.51 \\
\hline T5 & & & & 0.74 \\
\hline T6 & & & & 0.78 \\
\hline Eigenvalue & 9.80 & 1.76 & 1.20 & 1.10 \\
\hline Cumulative $\%$ of explained variance & 42.60 & 50.24 & 55.47 & 60.22 \\
\hline
\end{tabular}

Byrne (2010) argued that model satisfactoriness judgment should take into account for both theoretical and empirical justifications. Empirically, the current results from factor analysis suggested that the recovery/knowledge and responsiveness/assurance constructs should be combined. However, from theoretical perspective, both recovery and knowledge dimensions are conceptually dissimilar factors. Recovery is the effort an organization makes to recompense for the unconstructive effects of a failure or breakdown (Zemke \& Schaaf, 1989), and knowledge is defined as the competence and knowledge of service providers, and possession of necessary skills (Olorunniwo et al., 2006). Similar to the responsiveness dimension (the willingness to help customers and provide prompt service) and assurance (the knowledge and courtesy of employees and their abilities to convey trust and confidence), both of the constructs are conceptually very dissimilar variables (Zeithaml et al., 1990). In order to generate a more convincing result, discriminant validity was examined in next the section (see Table 5), which indicated that each construct is truly distinct from other constructs in the study 
(Hair et al., 2010).

4.2.2 Assessing Convergent and Discriminant Validity of Model

Table 4. Final results of the analysis of reliability and convergent validity

\begin{tabular}{|c|c|c|c|c|c|}
\hline Constructs & Items & $\begin{array}{l}\text { Standardized } \\
\text { loading }\end{array}$ & $t$ value & $\begin{array}{l}\text { Variance } \\
\text { Extracted }\end{array}$ & $\begin{array}{l}\text { Composite } \\
\text { Reliability }\end{array}$ \\
\hline \multirow[t]{3}{*}{ Tangibles } & $\mathrm{T} 1$ & 0.67 & 16.10 & 0.53 & 0.77 \\
\hline & T5 & 0.77 & 19.23 & & \\
\hline & T6 & 0.74 & 18.24 & & \\
\hline \multirow[t]{3}{*}{ Responsiveness } & R2 & 0.69 & 17.71 & 0.62 & 0.83 \\
\hline & $\mathrm{R} 3$ & 0.84 & 23.19 & & \\
\hline & R4 & 0.82 & 22.54 & & \\
\hline \multirow[t]{3}{*}{ Empathy } & E1 & 0.60 & 14.03 & 0.50 & 0.74 \\
\hline & E3 & 0.74 & 18.25 & & \\
\hline & E4 & 0.76 & 19.09 & & \\
\hline \multirow[t]{4}{*}{ Assurance } & A1 & 0.80 & 22.18 & 0.61 & 0.86 \\
\hline & A2 & 0.82 & 22.68 & & \\
\hline & A3 & 0.80 & 21.91 & & \\
\hline & A4 & 0.70 & 18.30 & & \\
\hline \multirow[t]{4}{*}{ Recovery } & $\mathrm{C} 1$ & 0.71 & 18.27 & 0.57 & 0.84 \\
\hline & $\mathrm{C} 2$ & 0.70 & 17.99 & & \\
\hline & C3 & 0.82 & 22.47 & & \\
\hline & $\mathrm{C} 4$ & 0.78 & 21.00 & & \\
\hline \multirow[t]{2}{*}{ Knowledge } & K1 & 0.77 & 19.58 & 0.56 & 0.72 \\
\hline & $\mathrm{K} 2$ & 0.72 & 18.07 & & \\
\hline \multirow[t]{3}{*}{ Food Quality } & F1 & 0.72 & 17.87 & 0.55 & 0.78 \\
\hline & F2 & 0.74 & 18.47 & & \\
\hline & F3 & 0.75 & 18.83 & & \\
\hline \multirow[t]{4}{*}{ Brand Awareness } & BA1 & 0.71 & 17.83 & 0.55 & 0.83 \\
\hline & BA2 & 0.71 & 17.92 & & \\
\hline & BA3 & 0.77 & 20.17 & & \\
\hline & BA4 & 0.77 & 20.22 & & \\
\hline \multirow[t]{2}{*}{ Brand Image } & BI1 & 0.70 & 15.92 & 0.61 & 0.75 \\
\hline & BI8 & 0.85 & 19.09 & & \\
\hline \multirow{6}{*}{ Brand Loyalty } & BL1 & 0.84 & 23.95 & 0.63 & 0.91 \\
\hline & BL2 & 0.86 & 24.95 & & \\
\hline & BL3 & 0.72 & 19.11 & & \\
\hline & BL4 & 0.82 & 22.97 & & \\
\hline & BL5 & 0.77 & 20.91 & & \\
\hline & BL6 & 0.77 & 21.05 & & \\
\hline
\end{tabular}

$\mathrm{X}^{2} / \mathrm{df}=2.224$, Root Mean Square Error of Approximation $($ RMSEA) $=0.047$, Standardized Root Mean Square Residual $(\mathrm{SRMR})=0.044$, Goodness-of-Fit Index $(\mathrm{GFI})=0.898$, Adjusted Goodness-of-Fit Index $(\mathrm{AGFI})=$ 0.874 , Normed Fit Index $(\mathrm{NFI})=0.901$, Comparative Fit Index $(\mathrm{CFI})=0.943$, Incremental Fit Index $(\mathrm{IFI})=$ 0.943 
Table 5. Result of the discriminant validity analysis

\begin{tabular}{|c|c|c|c|c|c|c|c|c|c|c|}
\hline Construct & 1 & 2 & 3 & 4 & 5 & 6 & 7 & 8 & 9 & 10 \\
\hline Variance Extracted & 0.63 & 0.61 & 0.55 & 0.55 & 0.56 & 0.57 & 0.61 & 0.50 & 0.62 & 0.53 \\
\hline 1. Brand Loyalty & 1 & & & & & & & & & \\
\hline 2. Brand Image & $\begin{array}{l}0.27 \\
(0.52 * *)\end{array}$ & 1 & & & & & & & & \\
\hline 3. Brand Awareness & $\begin{array}{l}0.21 \\
\left(0.45^{* *}\right)\end{array}$ & $\begin{array}{l}0.07 \\
(0.26 * *)\end{array}$ & 1 & & & & & & & \\
\hline 4. Food Quality & $\begin{array}{l}0.25 \\
\left(0.50^{* *}\right)\end{array}$ & $\begin{array}{l}0.08 \\
(0.29 * *)\end{array}$ & $\begin{array}{l}0.16 \\
\left(0.39^{* *}\right)\end{array}$ & 1 & & & & & & \\
\hline 5. Knowledge & $\begin{array}{l}0.25 \\
\left(0.50^{* *}\right)\end{array}$ & $\begin{array}{l}0.11 \\
(0.33 * *)\end{array}$ & $\begin{array}{l}0.13 \\
\left(0.36^{* *}\right)\end{array}$ & $\begin{array}{l}0.25 \\
\left(0.50^{* *}\right)\end{array}$ & 1 & & & & & \\
\hline 6. Recovery & $\begin{array}{l}0.25 \\
(0.50 * *)\end{array}$ & $\begin{array}{l}0.11 \\
(0.33 * *)\end{array}$ & $\begin{array}{l}0.11 \\
\left(0.33^{* *}\right)\end{array}$ & $\begin{array}{l}0.24 \\
\left(0.49^{* *}\right)\end{array}$ & $\begin{array}{l}0.45 \\
(0.67 * *)\end{array}$ & 1 & & & & \\
\hline 7. Assurance & $\begin{array}{l}0.28 \\
(0.53 * *)\end{array}$ & $\begin{array}{l}0.07 \\
\left(0.26^{* *}\right)\end{array}$ & $\begin{array}{l}0.20 \\
\left(0.45^{* *}\right)\end{array}$ & $\begin{array}{l}0.25 \\
\left(0.50^{* *}\right)\end{array}$ & $\begin{array}{l}0.37 \\
(0.60 * *)\end{array}$ & $\begin{array}{l}0.39 \\
\left(0.63^{* *}\right)\end{array}$ & 1 & & & \\
\hline 8. Empathy & $\begin{array}{l}0.15 \\
(0.39 * *)\end{array}$ & $\begin{array}{l}0.09 \\
\left(0.30^{* *}\right)\end{array}$ & $\begin{array}{l}0.32 \\
\left(0.56^{* *}\right)\end{array}$ & $\begin{array}{l}0.15 \\
\left(0.38^{* *}\right)\end{array}$ & $\begin{array}{l}0.20 \\
\left(0.45^{* *}\right)\end{array}$ & $\begin{array}{l}0.16 \\
\left(0.40^{* *}\right)\end{array}$ & $\begin{array}{l}0.28 \\
\left(0.53^{* *}\right)\end{array}$ & 1 & & \\
\hline 9. Responsiveness & $\begin{array}{l}0.25 \\
\left(0.50^{* *}\right)\end{array}$ & $\begin{array}{l}0.08 \\
\left(0.28^{* *}\right)\end{array}$ & $\begin{array}{l}0.10 \\
(0.32 * *)\end{array}$ & $\begin{array}{l}0.23 \\
\left(0.48^{* *}\right)\end{array}$ & $\begin{array}{l}0.31 \\
\left(0.56^{* *}\right)\end{array}$ & $\begin{array}{l}0.37 \\
\left(0.61^{* *}\right)\end{array}$ & $\begin{array}{l}0.44 \\
\left(0.66^{* *}\right)\end{array}$ & $\begin{array}{l}0.18 \\
(0.42 * *)\end{array}$ & 1 & \\
\hline 10. Tangibles & $\begin{array}{l}0.23 \\
\left(0.48^{* *}\right)\end{array}$ & $\begin{array}{l}0.06 \\
(0.24 * *)\end{array}$ & $\begin{array}{l}0.19 \\
\left(0.43^{* *}\right)\end{array}$ & $\begin{array}{l}0.30 \\
\left(0.55^{* *}\right)\end{array}$ & $\begin{array}{l}0.26 \\
\left(0.51^{* *}\right)\end{array}$ & $\begin{array}{l}0.27 \\
(0.52 * *)\end{array}$ & $\begin{array}{l}0.35 \\
\left(0.59^{* *}\right)\end{array}$ & $\begin{array}{l}0.18 \\
\left(0.43^{* *}\right)\end{array}$ & $\begin{array}{l}0.28 \\
\left(0.53^{* *}\right)\end{array}$ & 1 \\
\hline
\end{tabular}

Confirmatory factor analysis was conducted using AMOS software in order to study the convergent and discriminant validity of the model proposed. The final results of confirmatory factor analysis indicated a sensible fit of ten-factors model to the data in the basic of fit statistics $\left(\mathrm{X}^{2} / \mathrm{df}=2.224, \mathrm{RMSEA}=0.047\right.$, SRMR $=0.044$, $\mathrm{GFI}=0.898, \mathrm{AGFI}=0.874, \mathrm{NFI}=0.901, \mathrm{CFI}=0.943, \mathrm{IFI}=0.943)$ as indicated in Table 4 . Construct validity could be identified by satisfying both convergent validity and discriminant validity (Hair, 2010). Concerning convergent validity criteria, items will be removed if: (1) the standardized loadings scores below 0.5 (Hair et al., 2010); (2) any pair items of standardized residuals are greater than 14.01 (Hair et al., 2010); and (3) observed variable has two or more factor loadings exceeding the 10.101 threshold value (Byrne, 2010). The process led to the successive removal of T3, E2, BI2, BI3, BI6 and BI7 items. After the purification process, majority of the standardized loadings were above 0.7. As such, the results supported the issue of convergent validity (Anderson \& Gerbing, 1988). Furthermore, all constructs exceeded the cut-off value of composite reliability 0.7 (Nunnally, 1978) and variance extracted 0.5 (Fornell and Larker, 1981). With respect to discriminant validity, the variance extracted for each construct should be greater than the squared inter-construct correlations between a construct and all other constructs in the model (Fornell \& Larcker, 1981). Referring to Table 5, the analysis presented adequate results for all constructs. Again, this study have produced concrete empirical evidences to support the construct validity, particularly for "Recovery", "Knowledge", "Responsiveness", and "Assurance"; arguing that all the ten constructs are to be modeled as disaggregated multi-components measure. As a result, H1 was satisfied and accepted.

\subsubsection{Third-order Confirmatory Factor Analysis}

According to Bentler (2005), just-identified model will be incurred in second or third-order model, however, such problem can be solved by placing equality constraints on particular parameters at the upper level known to yield estimates that are approximately equal (Byrne, 2010). Critical ratio difference method was employed to constrain variances of the residuals associated with "Empathy" and "Knowledge" (second-order CFA) to be equal, as well as "Service quality" and "Brand image" (third-order CFA). As such, the higher order level of the model will be over-identified with one degree of freedom (Byrne, 2010). The third-order confirmatory factor analysis showed a sensible fit of consumer-based brand equity model to the data in the basic of fit statistics $\left(\mathrm{X}^{2} / \mathrm{df}=2.356, \mathrm{RMSEA}=0.049, \mathrm{SRMR}=0.057, \mathrm{GFI}=0.886, \mathrm{AGFI}=0.867, \mathrm{NFI}=0.889, \mathrm{CFI}=0.933, \mathrm{IFI}=\right.$ 0.933). Referring to Figure 2, all the first-order (second-order) constructs significantly influence service quality (brand equity) in the same way. The results have provided a strong validity and reliability of brand equity model. 
Importantly, it highlighted that service quality $(\beta=0.76)$ appears to be slightly more significant than brand awareness $(\beta=0.64)$ and brand image $(\beta=0.66)$ in the context of service shop.

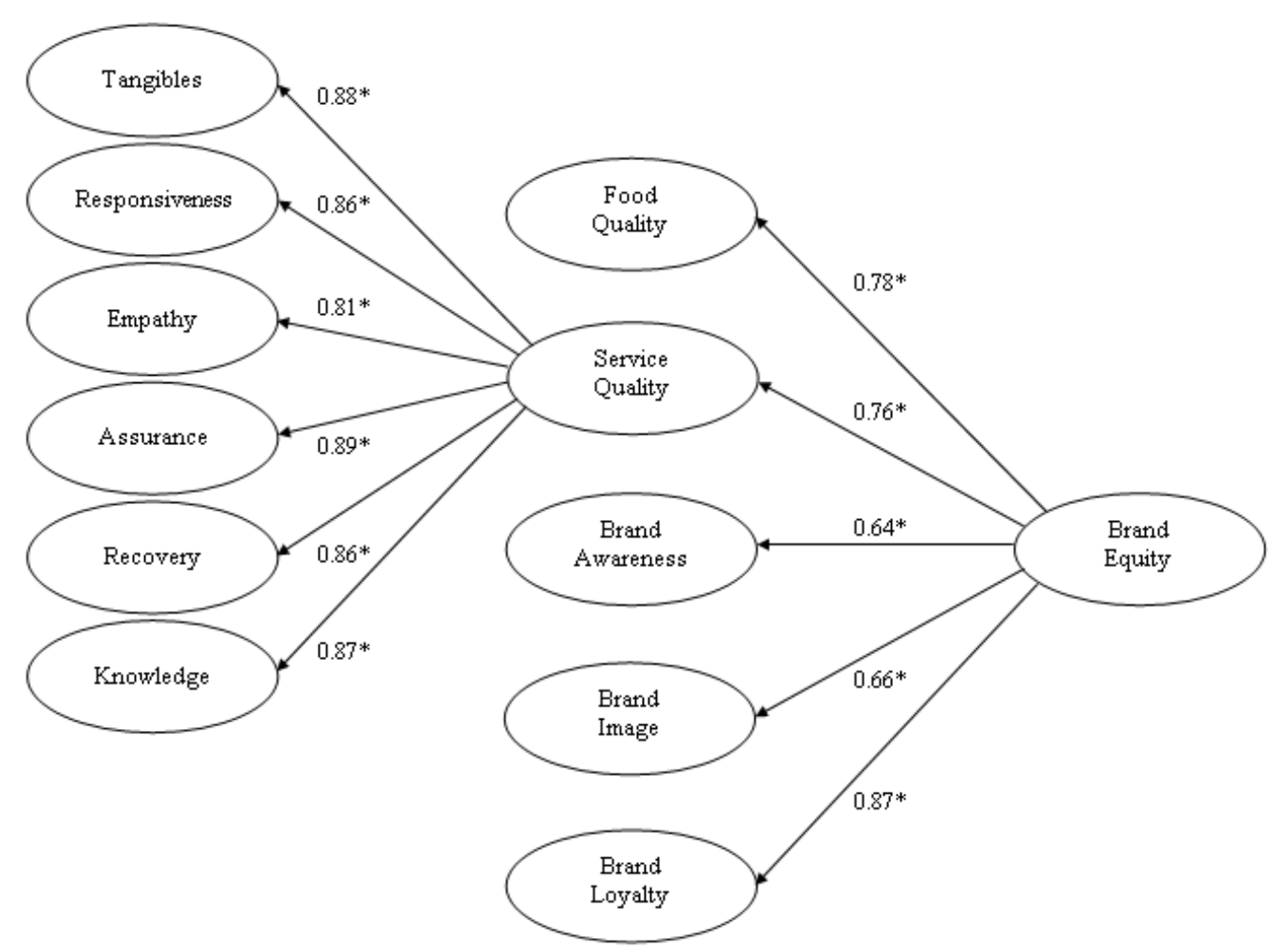

Figure 2. A conceptual framework for consumer-based brand equity in service shop

Note: * Indicates significance at $\mathrm{p}<0.05$

\subsubsection{Structural Model Result}

The goodness-of-fit statistics, indicating the overall acceptability of the structural model analyzed, were acceptable: $\mathrm{X}^{2} / \mathrm{df}=2.195, \mathrm{RMSEA}=0.046, \mathrm{SRMR}=0.048, \mathrm{GFI}=0.894, \mathrm{AGFI}=0.875, \mathrm{NFI}=0.898, \mathrm{CFI}=$ 0.941 and IFI $=0.942$. Most of the hypotheses were supported in the structural model and Table 6 presented the detailed results. Empirical results supported the six dimensions of service quality, as proposed by H1. Concentrating on the six identified dimensions of service quality, "Assurance" appeared to be the most important dimension $(\beta=0.88$, t value $=18.99)$, whereas "Empathy" was shown to be the least important dimension among other dimensions $(\beta=0.81, \mathrm{t}$ value $=12.17)$. The correlation between food quality and brand awareness was supported in $\mathrm{H} 2 \mathrm{a}$. With respect to $\mathrm{H} 2 \mathrm{~b}$, the causal relationship between food quality and brand image was not supported $(\beta=0.09$, t value $=1.03)$. In the same vein, $\mathrm{H} 2 \mathrm{~d}$ was not significant, thus the causal relationship between brand awareness and brand image was not supported $(\beta=0.13, \mathrm{t}$ value $=1.90)$. However, the results showed the level of brand loyalty is positively related to the evidence of food quality $(\beta=0.18, \mathrm{t}$ value $=2.80)$ and brand image $(\beta=0.39, \mathrm{t}$ value $=8.08)$. Thus, only H2a, H2c and H2e were supported. On the other hand, the result indicated that there was significant correlation between service quality and brand awareness $(\beta=0.59, \mathrm{t}$ value $=10.73)$. Besides, there were positive and significant values of service quality on brand image $(\beta=0.30, \mathrm{t}$ value $=3.28)$ and brand loyalty $(\beta=0.40, \mathrm{t}$ value $=6.20)$. 
Table 6. Results of the structural model

\begin{tabular}{|c|c|c|c|c|c|c|c|}
\hline & & & & $\begin{array}{l}\text { Standardized } \\
\text { coefficient }\end{array}$ & $t$ value & Sig. & Conclusion \\
\hline H1 & Service Quality & $\rightarrow$ & Tangibles & 0.87 & 14.72 & $* *$ & Supported \\
\hline H1 & Service Quality & $\rightarrow$ & Responsiveness & 0.85 & 15.59 & $* *$ & Supported \\
\hline H1 & Service Quality & $\rightarrow$ & Empathy & 0.81 & 12.17 & ** & Supported \\
\hline H1 & Service Quality & $\rightarrow$ & Assurance & 0.88 & 18.99 & ** & Supported \\
\hline H1 & Service Quality & $\rightarrow$ & Recovery & 0.85 & 16.15 & ** & Supported \\
\hline H1 & Service Quality & $\rightarrow$ & Knowledge & 0.86 & 17.83 & $* *$ & Supported \\
\hline H2a & Food Quality & $\leftrightarrow$ & Brand Awareness & 0.51 & 7.86 & $* *$ & Supported \\
\hline H2b & Food Quality & $\rightarrow$ & Brand Image & 0.09 & 1.03 & 0.30 & Not Supported \\
\hline H2c & Food Quality & $\rightarrow$ & Brand Loyalty & 0.18 & 2.80 & 0.01 & Supported \\
\hline H2d & Brand Awareness & $\rightarrow$ & Brand Image & 0.13 & 1.90 & 0.06 & Not Supported \\
\hline H2e & Brand Image & $\rightarrow$ & Brand Loyalty & 0.39 & 8.08 & $* *$ & Supported \\
\hline НЗа & Service Quality & $\leftrightarrow$ & Brand Awareness & 0.59 & 10.73 & $* *$ & Supported \\
\hline НЗа & Service Quality & $\rightarrow$ & Brand Image & 0.30 & 3.28 & $* *$ & Supported \\
\hline HЗb & Service Quality & $\rightarrow$ & Brand Loyalty & 0.40 & 6.20 & $* *$ & Supported \\
\hline \multicolumn{8}{|c|}{$\begin{array}{l}\mathrm{X}^{2} / \mathrm{df}=2.195, \text { Root Mean Square Error of Approximation }(\mathrm{RMSEA})=0.046 \text {, Standardized Root Mean Square } \\
\text { Residual }(\mathrm{SRMR})=0.048 \text {, Goodness-of-Fit Index }(\mathrm{GFI})=0.894 \text {, Adjusted Goodness-of-Fit Index }(\mathrm{AGFI})= \\
0.875 \text {, Normed Fit Index }(\mathrm{NFI})=0.898 \text {, Comparative Fit Index }(\mathrm{CFI})=0.941 \text {, Incremental Fit Index }(\mathrm{IFI})= \\
0.942\end{array}$} \\
\hline
\end{tabular}

\section{Conclusions}

This study attempted to develop a consumer-based brand equity model in the context of service shop. In this view, a conceptual model was proposed in which consumer perceptions of service quality functions as a sub-dimension of perceived quality in the service shop quadrant. The perception of service provider directly affects the creation of consumer's brand knowledge (Aziz \& Yasin, 2010; Bamert \& Wehrli, 2005, Keller, 2003). The results highlighted that the dimensions of service quality can be indicated by typology-specific, which is in line with the study of service factory (Olorunniwo et al., 2006). Particularly, this study had attempted to indicate a consistent classification scheme for services; which focused on the level of labor intensity and customer interaction. Based on results reported in the present study, service quality of the service shop was dominated by "Tangibles", "Responsiveness", "Empathy", "Assurance", "Recovery", and "Knowledge". Notably, reliability dimension failed to reveal an important role. However, researchers and practitioners should exercise caution in the understanding of these findings. For instance, there is a need to ensure the dependability, consistency, and accuracy of operation if the service shop does not have high investment for technology equipments and standard operating procedures. This study is consistent with the observation of Christodoulides and de Chernatony (2010), "a brand equity monitor should incorporate dimensions that drive value within the specific industry." The findings verified our initial hypothesis, that consumer-based brand equity in the service sector is best understood in a typology-specific, which is represented by four underlying dimensions, and perceived quality was decomposed into product quality and service quality. The results also indicated food quality (product quality) was loaded slightly greater than service quality on the brand equity factors. However, service quality was found to have significant causal relationships on brand awareness, brand image and brand loyalty. On the other hand, food quality (product quality) did not contribute significantly on brand image; contribute low t value and standardized coefficient ( 0.18 and 2.80 respectively) on brand loyalty even though there were statistical significance. The findings indicated that service quality is an important driver of consumer-based brand equity in the service shop, its causal effects is significantly greater than product quality in formatting favorable consumer response towards the brand.

\section{Managerial Implication}

The outcomes of the study provide an insight for service shop managers to develop relevant branding strategies 
which are applicable to their respective organizations. The results imply that service shop managers should significantly consider service quality when endeavoring to build definite brand equity from consumers' viewpoints. One of the most important conclusions that may be drawn from this study lies in the fact that service quality of a specific brand is found to be a vital element that affect the creation of brand equity in the service shop business. This may be due to the basis that service shop businesses need superior service delivery schemes to consumers. The results suggest that product quality alone do not guarantee strong, favorable, and unique associations linked to the brand image. Brand-building activity can be exercised by carefully allocating the efforts on service providers. The findings and strategies implications for each of the service quality dimensions observed are illustrated.

\subsection{Tangibles}

Restaurants' interior ambience and cleanliness are as important as they have influence on the dimensions of brand equity. The tangible attributes, such as the physical facilities (e.g., building, chairs, tables, washroom areas, and lightings) must be consistent with the theme of service shop and the setup of the premises, as consumers can easily recognize a certain brand of service shop. Managers can create standardized guidelines pertaining to both the interior and exterior designs. Given the limited amount of space available in the chosen premises, it is crucial that sufficient sitting capacity could accommodate a certain number of consumers at a given time, whilst maintaining the comfort level. Constant supervisions are required to assure compliance to the set guidelines. Managers should provide intensive training to the employees in the area of food preparation, ranging from selection of raw materials to food presentation techniques. The ongoing training for human capital will help managers to instill a work culture that emphasizes cleanliness, tidiness and appropriate dress code.

\subsection{Responsiveness}

Service shop managers should emphasize training programs and seminars that are based on people skills to create employees that have the capabilities engaging consumers pleasantly. The focus of people skills should be based on the improvement of communication, which is vital so that employees are able to breeze through in engaging consumers. Reward system such as "Employee of the Month" exercises and monetary incentives can be used to encourage responsiveness of employees towards consumer needs. Evaluation of employees' responsiveness can be carried out through consumers' testimonials in terms of their perceptions towards employees' people skills. An employee with a great sense of hospitality to consumers would reflect a favorable brand image. In building brand loyalty through responsiveness to consumer needs, managers should focus on implementing a reward system to employees, who effectively and proactively handle consumers' complaints. Managers can implement merit points accumulation programs for employees, in which each employee are to accumulate as many merit points from consumers. Accumulated merits points can be converted to cash vouchers, annual leaves, or even a short-holiday incentive. This reward system will encourage the employees to work for their points through providing the best consumer service, hence creating brand equity.

\subsection{Empathy}

To create brand equity for service shop, managers should position themselves in showing much empathy or have better understanding in fulfilling consumer needs, compared to the competitors, such as the availability of sauces, sugar, and black pepper. Strategically located premises are one strategy that enables consumers to conveniently locate and visit the premise. Managers should consider that the 'chosen location' for the premise provides adequate parking spaces, a smooth traffic flow, and notable entrance. Innovation in new set meals or introducing new flavors from time to time enables service shop to a reach wider range of consumers, while retaining the existing consumers.

\subsection{Ansurance}

Installation of CCTV at various strategic points in the premise would instill a sense of security among consumers. For example main entrances, cash points and parking areas. In addition to that, well-lit parking areas are favorable because these areas are highly prone to crimes. Most employees are unaware about the consequences of mishandling of customers' financial information. To address that, collaborations with professionals from the banking industry to develop training programs for employees regarding the appropriateness in handling financial information of consumers are recommended. Employees must be trained to be tactful when requesting for customers' confidential information, namely credit card numbers and other personal information, to assure consumers that the confidential information disclosed by them are handled professionally and diligently.

\subsection{Recovery}

The service shop must create service recovery guidelines for employees' compliance to empower them to take 
corrective measures and actions, when an error has taken place, without the authorization of their respective superiors. The service recovery guidelines could be adapted from "Service Recovery Strategies" developed by de Run and Kusyarnadi (2008). The strategies comprise the ways to countermeasure errors, based on the level of severity, namely spoken, minor actions and major actions.

\subsection{Knowledge}

Knowledgeable employees are created through continuous updating of employees knowledge with regards to food recommendations, menu offerings and promotions. Conducting briefings before the opening hours, and sharing of morning agendas, for example daily promotions and special food menus enhance the information and communication flows amongst the employees. In addition, employees should also be equipped with basic food nutrition facts on each meal offered. Managers are recommended to establish a food nutrition fact database to provide updated information and to ease the process for employees to acquire relevant knowledge. The findings of Yoo et al. (2000) only indicated traditional "4 Ps" marketing activities, as referred to by Judd (2002), people-power should be managed, institutionalized, and formalized as distinguish component of the marketing mix. In conclusion, to enhance the potency of brand, service shop managers must concentrate on service quality; increase the quality of service providers by improving physical environment quality as well as the quality of employees, especially front-line operators.

\section{Limitations}

The study used restaurant chains to represent service shop. Therefore, future studies should include other types of service shop; for example hospitals, auto repairs, and other repair services. Besides, future studies should examine service shop, service factory, mass service, and professional service simultaneously. This will give the opportunity to make assessments between different service quadrants. As for the current study, the dimensions of brand equity are adopted and modified from previous research studies (Aaker, 1991; Keller, 1993; Kim \& Kim 2005). There is disconfirmation of brand equity dimensions up-to-date, for instance Yoo et al.'s (2000) brand loyalty, perceived quality and brand association/awareness dimensions were based on athletic shoes, camera film, and television sets. Angel and Manuel (2005) replaced brand association as brand image in durable goods study. Boo et al. (2009) further classified brand equity dimensions of tourism destination as brand value, brand awareness, brand experience, and brand loyalty. Thus, different industries contributed to the dissimilarity of brand equity dimensions. Future studies may investigate the universal dimensions of consumer-based brand equity in service industry by typology-specific. The design and implementation of the non-probability sampling method constitutes another significant limitation. Arguably, respondents included in this study may not truly represent the populations of consumers in service shop. From this viewpoint, random sampling will be more representative, in increasing the reliability and validity of the data analysis and results (Kim \& Kim, 2005). According to Hair et al. (2010), latent constructs should be indicated by at least three observed variables; in other words, latent factors should be statistically identified. In this study, both knowledge and brand image were operationalized by two observed variables, which makes the psychometric properties of constructs questionable. Even though Malaysia is a multicultural society, there are still cultural variations that exist between Western and Eastern notions of consumer response. Thus, simultaneous use of samples from multiple cultures, especially geographical different samples should be considered in future studies. Furthermore, invariance test should be performed to investigate the equivalence of brand equity dimensionality and structural model across different cultures.

\section{Acknowledgements}

This research study was funded by Multimedia University Special Funding for Social Sciences Research (SFSCR). The authors would like to thank David Tong Yoon Kin, Eze Uchenna Cyril, and Sia Bik Kai, for insightful comments on earlier draft of this manuscript.

\section{References}

Aaker, D. A. (1991). Managing brand equity. The Free Press, New York, NY.

Aaker, D. A. (1996). Measuring brand equity across products and markets. The Free Press, New York, NY.

Anderson, J. C., \& Gerbing, D. W. (1988). Structural equation modeling in practice: A review and recommend two-step approach. Psychological Bulletin, 103, 411-423. http://dx.doi.org/10.1037/0033-2909.103.3.411

Andreas, H. Z. (2001). Relative attitudes and commitment in customer loyalty models: Some experiences in the commercial airline industry. International Journal of Service Industry Management, 12(3), 269-294. http://dx.doi.org/10.1108/EUM0000000005521 
Angel, F. V.-R., \& Manuel, J. S.-F. (2005). The impact of marketing communication and price promotion on brand equity. Journal of Brand Management, 12(6), 431-44. http://dx.doi.org/10.1057/palgrave.bm.2540238

Aronson, E., Ellsworth, P. C., Carismith, J. M., \& Gonzales, M. H. (1990). Methods of research in social psychology (2nd ed.). New York, NY.

Aydin, S., \& Ozer, G. (2005). The analysis of antecedents of customer loyalty in the Turkish mobile telecommunication market. European Journal of Marketing, 39(7/8), 910-925. http://dx.doi.org/10.1108/03090560510601833

Aziz, N. A., \& Yasin, N. M. (2010). Analyzing the brand equity and resonance of banking services: Malaysian consumer perspective. International Journal of Marketing Studies, 2(2), 180-189.

Bamert, T., \& Wehrli, H. P. (2005). Service quality as an important dimension of brand equity in Swiss services industries. Managing Service Quality, 15(2), 132-141. http://dx.doi.org/10.1108/09604520510585325

Bello, D. C., \& Holbrook, M. B. (1995). Does an absence of brand equity generalize across product classes?. Journal of Business Research, 34(2), 125-131. http://dx.doi.org/10.1016/0148-2963(95)00008-G

Bentler, P. M. (1983). Some contributions to efficient statistics in structural models: Specification and estimation of moment structures. Psychometrika, 48(4), 493-517. http://dx.doi.org/10.1007/BF02293875

Bentler, P. M. (2005). EQS 6 Structural equations program manual. Multivariate Software, Encino, CA.

Boo, S., Busser, J., \& Baloglu S. (2009). A model of customer-based brand equity and its application to multiple destinations. Tourism Management, 29, 219-231. http://dx.doi.org/10.1016/j.tourman.2008.06.003

Boulding, W., \& Kirmani, A. (1993). A consumer-side experimental examination of signaling theory: Do consumers perceive warranties as signals of quality? Journal of Consumer Research, 20(1), 111-123. http://dx.doi.org/10.1086/209337

Brady, M. K., \& Cronin, J. J. (2001). Some new thoughts on conceptualizing perceived service quality: A hierarchical approach. Journal of Marketing, 65(3), 34-49. http://dx.doi.org/10.1509/jmkg.65.3.34.18334

Browne, M. W., \& Cudeck, R. (1993). Alternative ways of assessing model fit. In K. A. Bollen \& J. S. Long (Eds.), Testing Structural Equation Models (pp. 136-162). Sage, Newbury Park, CA.

Byrne, B. M. (2010). Structural equation modeling with AMOS: Basic concepts, applications, and programming (2nd ed.). Lawrence Erlbaum Associates, Mahwah, New Jersey.

Christodoulides, G., \& de Chernatony, L. (2010). Consumer-based brand equity conceptualization and measurement. International Journal of Market Research, 52(1), 43-66. http://dx.doi.org/10.2501/S1470785310201053

Cook, D. P., Goh, C., \& Chung, C. H. (1999). Service typologies: A state of the art survey. Production \& Operations Management, 8(3), 318-338. http://dx.doi.org/10.1111/j.1937-5956.1999.tb00311.x

Cronin, J. J., \& Taylor, S. A. (1992). Measuring service quality: A reexamination and extension. Journal of Marketing, 56(3), 55-68. http://dx.doi.org/10.2307/1252296

de Run, E. C., \& Kusyarnadi, H. (2008). Service recovery strategies in western based fast food restaurants: A structural equation model test. International Journal of Business and Society, 9(2), 33-42.

Dodds, W. B., Monroe, K. B., \& Grewal, D. (1991). Effects of price, brand, and store information on buyers' product evaluations. Journal of Marketing Research, 28(3), 307-319. http://dx.doi.org/10.2307/3172866

Esch, F. R., Langner, T., Schmitt, B. H., \& Geus, P. (2006). Are brands forever? How brand knowledge and relationships affect current and future purchases. Journal of Product \& Brand Management, 15(2), 98-105. http://dx.doi.org/10.1108/10610420610658938

Flavián, C., Guinalíu, M., \& Gurrea, R. (2006). The role played by perceived usability, satisfaction and consumer trust on website loyalty. Information and Management, 43(1), 1-14. http://dx.doi.org/10.1016/j.im.2005.01.002

Fornell, C., \& Larcker, D. (1981). Structural equation models with unobservable variables and measurement error. Journal of Marketing Research, 18(1), 39-50. http://dx.doi.org/10.2307/3151312

Gil R. B., Andrés E. F., \& Salinas E. M. (2007). Family as a source of consumer-based brand equity. Journal of Product \& Brand Management, 16(3), 188-199. http://dx.doi.org/10.1108/10610420710751564

Grewal, D., Krishnan, R., Baker, J., \& Borin, N. (1998). The effect of store name, brand name, and price 
discounts on consumer's evaluations and purchase intentions. Journal of Retailing, 74(3), 331-352. http://dx.doi.org/10.1016/S0022-4359(99)80099-2

Gwinner, K. P., Gremler, D. D., \& Bitner, M. J. (1998). Relational benefits in services industries: The customer's perspective. Journal of the Academy of Marketing Science, 26(2), 101-114. http://dx.doi.org/10.1177/0092070398262002

Hair, J. F., Black, W. C., Babin, B. J., \& Anderson, R. E. (2010). Multivariate data analysis: A global perspective (7th ed.). Prentice Hall, Upper Saddle River, New Jersey.

Hennig-Thurau, T., \& Klee, A. (1997). The impact of customer satisfaction and relationship quality on customer retention: A critical reassessment and model development. Psychology and Marketing, 14(8), 737-64. http://dx.doi.org/10.1002/(SICI)1520-6793(199712)14:8<737::AID-MAR2>3.0.CO;2-F

Henry, T., Catherine C., \& Ada, L. (2010). An exploratory study of the relationship between customer-based casino brand equity and firm performance. International Journal of Hospitality Management, 29, 754-757.

Hoyer, W. D., \& Brown, S. P. (1990). Effects of brand awareness on choice for a common, repeat-purchase product. Journal of Consumer Research, 17(2), 141-148. http://dx.doi.org/10.1086/208544

Johns, N., \& Howard, A. (1998). Customer expectations versus perceptions of service performance in the foodservice industry. International Journal of Service Industry Management, 9(3), 248-256. http://dx.doi.org/10.1108/09564239810223556

Judd, V. C. (2002). Achieving a customer orientation using people-power, the 5th "P". European Journal of Marketing, 37(10), 1301-1313. http://dx.doi.org/10.1108/03090560310487112

Kandampully, J., \& Hu, H. (2007). Do hoteliers need to manage image to retain loyal customer? International Journal of Contemporary Hospitality Management, 19(6), 435-443. http://dx.doi.org/10.1108/09596110710775101

Keller, K. L. (1993). Conceptualizing, measuring, and managing customer-based brand equity. Journal of Marketing, 57(1), 1-22. http://dx.doi.org/10.2307/1252054

Keller, K. L. (1998). Strategic brand management: Building, measuring, and managing brand equity. Prentice-Hall, Upper Saddle River, New Jersey.

Keller, K. L. (2003). Building, measuring and managing brand equity (2nd ed.). Prentice-Hall, Upper Saddle River, New Jersey.

Kim, H. B., \& Kim, W. G. (2005). The relationship between brand equity and firms' performance in luxury hotels and chain restaurants. Tourism Management, 26, 549-560. http://dx.doi.org/10.1016/j.tourman.2004.03.010

Kim, W. G., \& Kim, H. B. (2004). Measuring customer-based restaurant brand equity: Investigating the relationship between brand equity and firms' performance. Cornell Hotel \& Restaurant Administration Quarterly, 45(2), 115-131. http://dx.doi.org/10.1177/0010880404264507

Kivela, J., Inbakaran, R., \& Reece, J. (1999). Consumer research in the restaurant environment, Part 1: A conceptual model of dining satisfaction and return patronage. International Journal of Contemporary Hospitality Management, 11(5), 205-222. http://dx.doi.org/10.1108/09596119910272739

Lapierre, J. (1996). Service quality: The construct, its dimensionality, and its measurement. In T. A. Swartz, D. E. Bowen \& S. W. Brown (Eds.), Advances in Services Marketing and Management (Vol. 5, pp. 45-70).

Lovelock, C. H. (1983). Classifying services to gain strategic marketing insights. Journal of Marketing, 47(3), 9-20. http://dx.doi.org/10.2307/1251193

Lu, C. S., Lai, K. H., \& Cheng, T. C. E. (2007). Application of structural equation modeling to evaluate the intention of shippers to use internet services in liner shipping. European Journal of Operational Research, 180(2), 845-867. http://dx.doi.org/10.1016/j.ejor.2006.05.001

Malai, V., \& Speece, M. (2010). Perceived customer value relationships and cultural impacts on its. Retrieved from http://smib.vuw.ac.nz:8081/WWW/ANZMAC2004/CDsite/papers/Malai1.PDF (January 18, 2011).

Marsh, H. W., \& Hocevar, D. (1985). Application of confirmatory factor analysis to the study of self-concept: First and higher order factor models and their invariance across groups. Psychological Bulletin, 97(3), 562-582. http://dx.doi.org/10.1037/0033-2909.97.3.562

Muller, C. C. (1998). Endorsed branding: The next step in restaurant-brand management. Cornell Hotel \& Restaurant Administration Quarterly, 39(3), 90-97. http://dx.doi.org/10.1177/001088049803900317 
Nunnally, J. C. (1978). Psychometric Theory. McGraw-Hill, New York, NY.

Olorunniwo, F., Hsu, M. K., \& Udo, G. J. (2006). Service quality, customer satisfaction, and behavioral intentions in the service factory. Journal of Services Marketing, 20(1), 59-72. http://dx.doi.org/10.1108/08876040610646581

Parasuraman, A., Zeithaml, V. A., \& Berry, L. L. (1985). A conceptual model of service quality and its implications for future research. Journal of Marketing, 49(4), 41-50. http://dx.doi.org/10.2307/1251430

Parasuraman, A., Zeithaml, V. A., \& Berry, L. L. (1988). SERVQUAL: A multiple item scale for measuring customer perception of service quality. Journal of Retailing, 64(Spring), 12-37.

Paul, W. C. S., Gary, Y. Y.-Y., \& Hsiao, C.-R. (2010). The effect of store image and service quality on brand image and purchase intention for private label brands. Australasian Marketing Journal, 19(1), 30-39.

Pike, S., Bianchi, C., Kerr, G., \& Patti, C. (2010). Consumer-based brand equity for Australia as a long-haul tourism destination in an emerging market. International Marketing Review, 27(4), 434-449. http://dx.doi.org/10.1108/02651331011058590

Roberts, J., Morrison, P., Chandrashekaran, M., \& Gordon, A. (2004). Measuring sources and outcomes of brand equity. Communication in ANZMAC Conference, Australian and New Zealand Marketing Conference.

Rosa R. E., \& Riquelme H. E. (2008). Brand equity for online companies. Marketing Intelligence \& Planning, 26(7), 719-742. http://dx.doi.org/10.1108/02634500810916681

Rust, R. T., \& Oliver, R. L. (1994). Service Quality: Insights and managerial implications from the Frontier. In T. R. Roland \& L. O. Richard (Eds.), Service Quality: New Directions in Theory and Practice (pp. 1-19). Sage, Thousand Oaks, CA.

Schmenner, R. W. (1986). How can service businesses survive and prosper? Sloan Management Review, 27(3), 21-32.

Simon, C. J., \& Sullivan, M. W. (1993). The measurement and determinants of brand equity a financial approach. Marketing Science, 12(1), 28-52. http://dx.doi.org/10.1287/mksc.12.1.28

Srivastava, R., \& Shocker, A. D. (1991). Brand equity: A perspective on its meaning and measurement. Marketing Science Institute Working Paper Series, Report 91-124, Marketing Science Institute, Cambridge, MA.

Styles, C., \& Ambler, T. (1995). Brand management. In Crainer, S. (Ed.), Financial times handbook of management (pp. 581-593). Pitman, London.

Szymanski, D. M., Bharadwaj, S. G., \& Varadarajan, P. R. (1993). An analysis of the market share-profitability relationship. Journal of Marketing, 57(3), 1-18. http://dx.doi.org/10.2307/1251851

Tan, T. M., \& Devinaga, R. (2011). A review of online trust branding strategies of financial services industries in Malaysia and Australia. Advances in Management and Applied Economics, 1(1), 125-150.

Tan, T. M., Hishamuddin, I., \& Devinaga, R. (2011). Hierarchical chain of consumer-based brand equity: Review from the fast food industry. International Business \& Economics Research Journal, 10(9), 67-80.

Tan, T. M., Tan, S.-M., William L., Michelle, O. S. F., \& Liew, T. W. (2012). Does brand equity model vary between female and male? Result of an empirical investigation. International Journal of Research in Management, 2(3).

Tong, X. (2006). Creation of brand equity in the Chinese clothing market. Unpublished doctoral dissertation, University of Missouri, Columbia, US.

Tong, X., \& Hawley, J. M. (2009). Measuring customer-based brand equity: Empirical evidence from the sportswear market in China. Journal of Product \& Brand Management, 18(4), 262-271. http://dx.doi.org/10.1108/10610420910972783

Wang, H. Z., Wei, Y. J., \& Yu, C. L. (2008). Global brand equity model: combining customer-based with product-market outcome approaches. Journal of Product \& Brand Management, 17(5), 305-316. http://dx.doi.org/10.1108/10610420810896068

Xu, J. B., \& Andrew C. (2009). A conceptual framework of hotel experience and customer-based brand equity. Some research questions and implications. International Journal of Contemporary Hospitality Management, 22(2), 174-193. http://dx.doi.org/10.1108/09596111011018179 
Yasin, N. M., Noor, M. N., \& Mohamad, O. (2007). Does image of country-of-origin matter to brand equity? Journal of Product \& Brand Management, 16(1), 38-48. http://dx.doi.org/10.1108/10610420710731142

Yoo, B., Donthu, N., \& Lee, S. (2000). An examination of selected marketing mix elements and brand equity. Journal of the Academy of Marketing Science, 28(2), 195-212.

Zain, R. (2007). Pengaruh product quality dan service quality terhadap tingkat brand awareness nasabah: Studi kasus Permata Bank Syariah. In Partial Fulfillment of the Requirement for the Degree Master of Science. Universitas Indonesia Eprints.

Zeithaml, V. A., Parasuraman, A., \& Berry, L. L. (1990). Delivering service quality. The Free Press, New York, NY.

Zemke, R., \& Schaaf, R. (1989). The service edge: 101 companies that profit from customer care. NAL Books, New York, NY. http://dx.doi.org/10.1177/0092070300282002

\section{Appendix}

Appendix 1. Consumer-based brand equity instruments in service shop

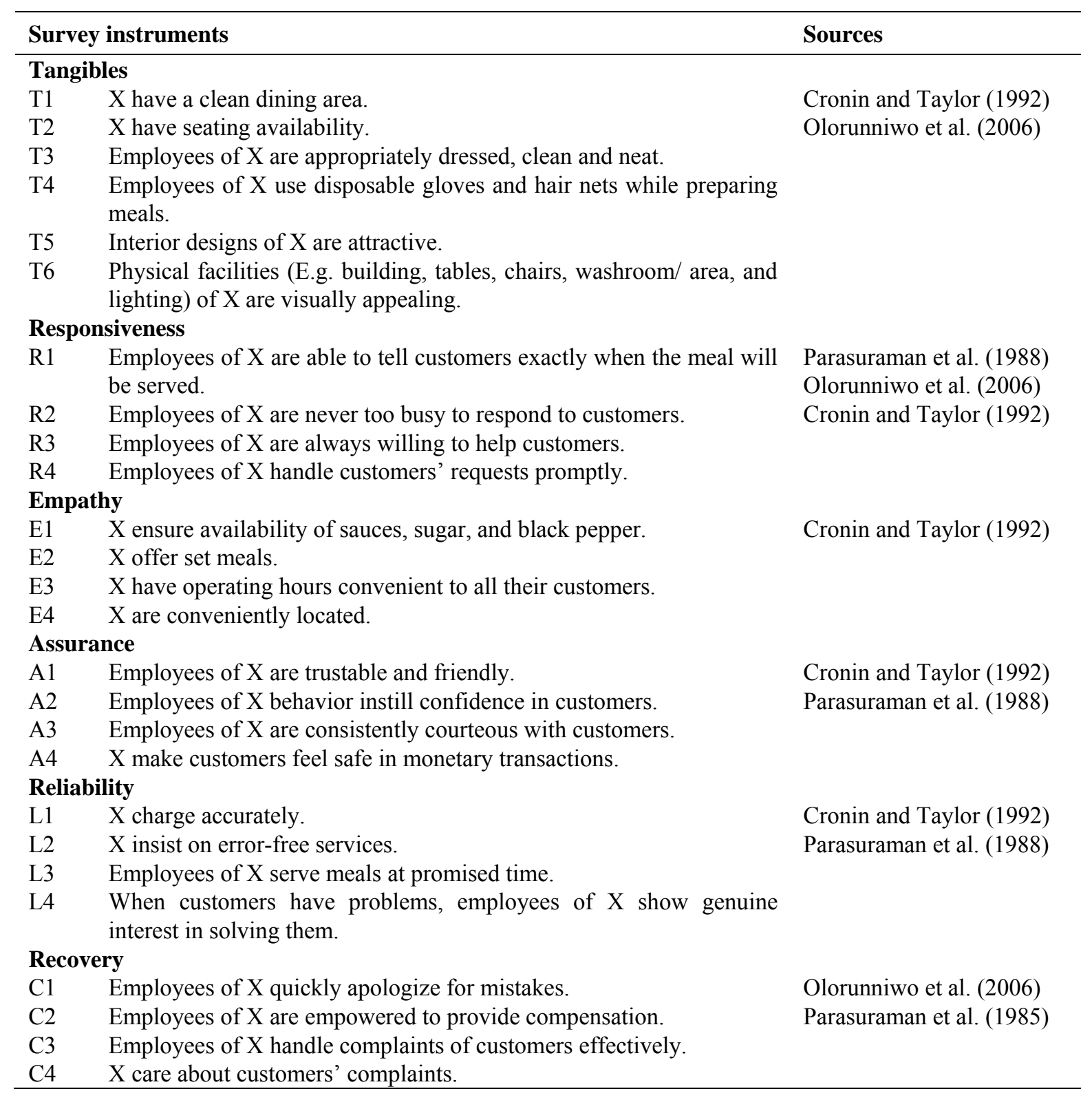


Appendix 1. Consumer-based brand equity instruments in service shop (continue)

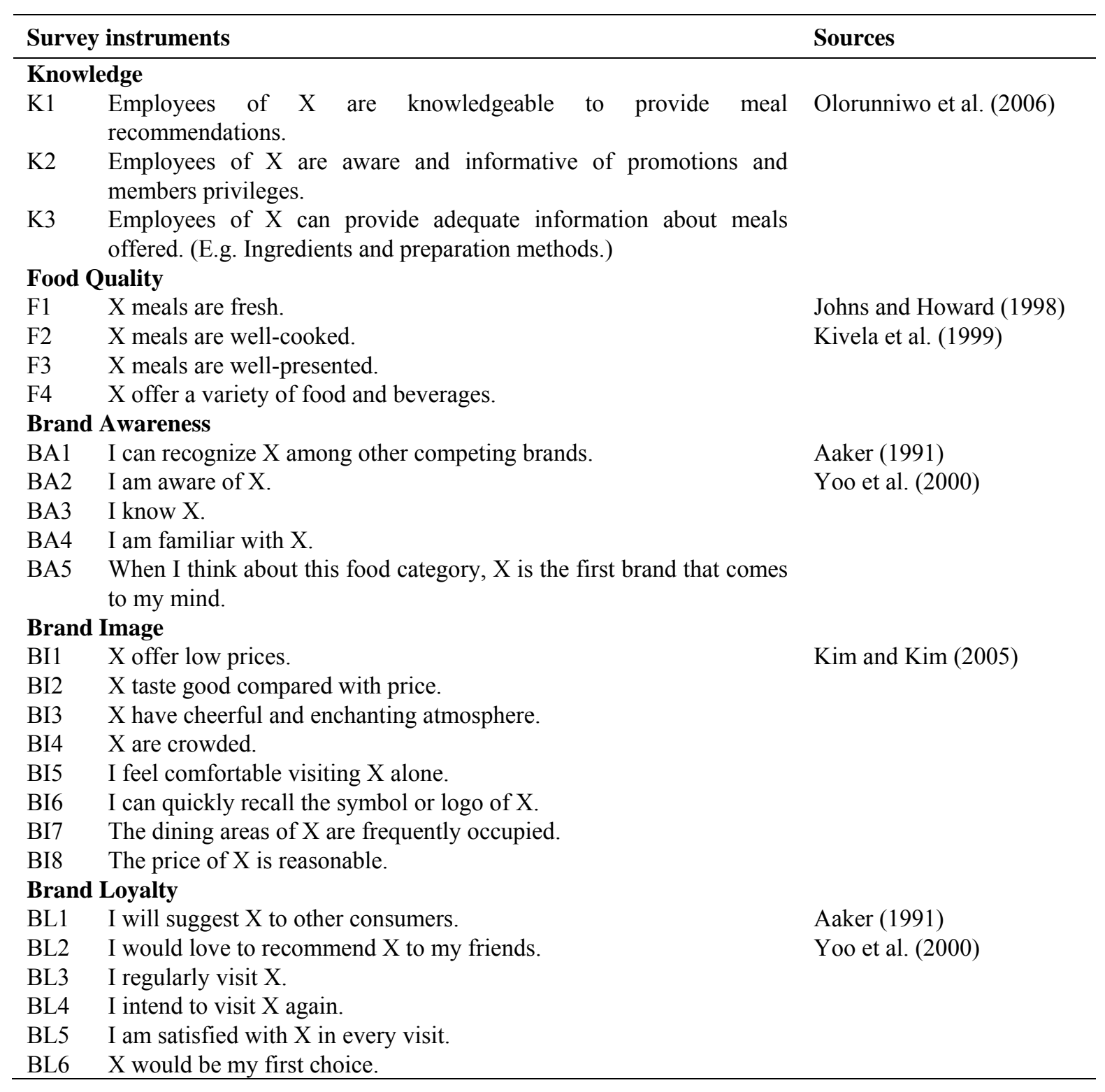

